\title{
Design and Application of a Novel Sand Table Simulation Teaching System involving International Trade Factors
}

\author{
Mingliang Yu ${ }^{1, a}$, Jiadong Huang ${ }^{1, b}$, Ye Huang ${ }^{2, ~ c}$, and Tian Tao ${ }^{1, d}$ \\ ${ }^{1}$ Labs of Economics and Management, University of Shanghai for Science and Technology, Shanghai 200093, \\ China \\ ${ }^{2}$ Fintech Unstitute, Shanghai University of Finance and Economics, Shanghai 200433, China \\ aymllw@163.com, b1463890151@qq.com, 'huang.ye@sufe.edu.cn, ${ }^{\mathrm{d}}$ Taotian2005@126.com
}

Keywords: Sand Table Simulation Teaching, International Trade Method, Enterprise Operation Simulation.

\begin{abstract}
The sand table teaching platform has been widely adopted in college economic and management education, nevertheless the international trade related methods are seldom mentioned. In this paper, a novel san table simulation teaching system involving some significant international trade are presented based on the touch integrated sand table teaching platform independently developed by our school. By combining the raw materials procurement, delivery and account in the international trade with current sand table teaching system, a general solution is put forward in teaching application and teaching expansion.
\end{abstract}

\section{Introduction}

In recent years, the teaching of sand table has developed rapidly. The teaching process adopts experiential, research-based and competitive self-learning teaching methods, immersing students in the virtual competitive business environment to experience the real operation of the company in the sand table deduction to arousing their enthusiasm and to encourage indigenous innovation. In the real international trade, all aspects of raw material procurement, delivery and billing period will have an impact on the final overall labor productivity, and therefore affecting corporate profits. The old sand table software did not take into account the impact of the various issues described above on productivity.

The lack of international trade factors affecting the authenticity in sand table simulation teaching:

(1) In the authentic business environment, the international trading awareness is essential to the company, without which the operation result of the sand table varies from that in real world.

(2) Raw material procurement, delivery and billing period etc. are inevitable in sand table simulation teaching

Based on the above questions, the Economic Management Experimental Center of Shanghai University of Technology conducted relevant research and actively applied the awareness of international trade to the new sand table teaching system. The novel sand table teaching system is robust enough to involve the international economy and trade theories via modifying relevant rules. It highlights the importance of the awareness towards international economy and trade, and render the simulation closer to the company operation in the real business environment.

\section{International Trade Awareness}

The actual operation of the company is inseparable from the theoretical guidance of the international economic and trade methods. The awareness of international trade is the product of trade development practice, and it is the principle and method of guiding the exchange of goods and services between different groups. The following are the main trade awareness of the additional modules in this sandbox system: 


\subsection{Risk awareness.}

The international economy and trade pursue the exchange of goods and services, in order to achieve a win-win situation (to increase the overall efficiency rate), must establish risk awareness, and seek to complete the work in the lowest cost and more efficient way. Based on the current status of the sandbox system, in the international economic and trade add-on module, the operator's risk awareness is strengthened through a series of new rules.

\subsection{Compliance awareness.}

In the operation of the sandbox system, the operator needs to constantly find problems and solve problems. Under a reasonable rule system, according to the actual situation of the simulation, the production, procurement, orders, etc. are reasonably analyzed and processed, and finally Improve the goal of maximizing overall efficiency, and the new rules of the sector effectively improve the clarity of the use of indicators, and can ensure that the traditional software is based on the limitations of pre-defined business model operations.

\subsection{Integrity awareness.}

In the international trading system, involving trade between countries and countries, regions and regions, in order to combine the situation of different countries and regions, we must establish a unified standard of integrity to ensure the smooth progress of trade, targeting the target The specific situation chooses the appropriate checkout method, and combines the globalization of international trade and trade to achieve good trade results.

\section{Different raw material procurement rules applied to the sand table simulation teaching system}

Raw material procurement mainly includes two aspects: transportation cycle and unit price. The transportation cycle refers to the trade exchange activities carried out in combination with the domestic and international markets, and the raw materials selected will inevitably be based on the principle of trade, that is, to achieve the most effective and reasonable output of the final goods and services. Under the current general trend of global economic integration, perhaps considering whether to choose domestic or foreign is one of the factors that need to be verified. The unit price refers to the cost of the selected raw materials in the market as the cost of production and construction based on the market selection. Table 1 shows that the rational rules for the purchase of raw materials in combination with domestic and international conditions.

Table 1 Raw materials procurement in domestic and foreign markets

\begin{tabular}{|c|c|c|c|c|}
\hline & $\begin{array}{c}\text { Domestic transportation } \\
\text { cycle }\end{array}$ & $\begin{array}{c}\text { Foreign transportation } \\
\text { cycle }\end{array}$ & $\begin{array}{c}\text { Domestic unit } \\
\text { price }\end{array}$ & $\begin{array}{c}\text { Foreign unit } \\
\text { price }\end{array}$ \\
\hline R1 & 1 & 2 & 10 & 6 \\
\hline R2 & 1 & 2 & 10 & 6 \\
\hline R3 & 2 & 3 & 10 & 6 \\
\hline R4 & 2 & 3 & 10 & 6 \\
\hline
\end{tabular}

In the new system, different raw materials will be priced from multiple perspectives, and the teaching will be closer to the actual situation.

\section{Different delivery condition rules applied to sand table simulation teaching system}

In practical teaching, the main way in which this theory can be applied to the new system is to reset the delivery rules, optimize and maintain the rules. In the past sand table teaching system, only the limitation of the delivery period was considered, that is, the delivery of the order was guaranteed within the specified time. For the delivery rules, under the new rules, the relationship between the 
product and the delivery can be considered from more angles, and the sand table simulation teaching can be more in line with the actual situation.

For example, in terms of the delivery cycle of the product, the terminology of international economics and trade is integrated. According to the established basis of production capacity, raw material quality, etc., different delivery methods can be selected according to various factors such as account period and capital situation. The cost of additional payment for each different delivery is different, and different delivery methods, depending on the actual situation, the transaction price and transportation time of the final product will fluctuate.

Initially implementation rules. When the delivery method is determined, the delivery rules are as follows, the fees to be paid for different delivery cycles are different, and the maximum cost shall not exceed $5 \%$ of the transaction volume, and the quality decline shall not exceed $20 \%$. As shown in table 2.

Table 2 Product delivery rules

\begin{tabular}{|l|l|c|l|l|}
\hline & Cost(\%) & Transportation period & quality & unit price (\%) \\
\hline FCA & 1 & 0 & Lower $12 \%$ & Up 5\% \\
\hline FOB & 1 & 0 & Lower $10 \%$ & Up 8\% \\
\hline CFR & 3 & 1 & Lower $8 \%$ & Up $10 \%$ \\
\hline CIF & 3 & 1 & Lower $5 \%$ & Up $10 \%$ \\
\hline CPT & 5 & 0 & Lower $15 \%$ & Up 15\% \\
\hline CIP & 5 & 1 & Lower $20 \%$ & Up 20\% \\
\hline
\end{tabular}

\section{Account period rules applied to sand table simulation teaching system}

The ultimate goal of the transaction is to make a profit, and after the exchange of goods and services, there will be a question about the choice of the account period, that is, choosing a different collection method will make the capital flow of the company completely different. In the actual teaching, combining the terms of the international trade term with the sandbox simulation teaching system will make the whole simulation more in line with the actual situation, and only achieve the most complete overall, in order to achieve the purpose of maximizing the interests of the enterprise.

In the new sandbox simulation system, the quality of different products has been designed to vary depending on factors such as raw materials and research and development. In the process of continuous improvement of future rules, we will try to choose different delivery methods based on the product quality, combined with the consideration of the billing cycle, and the profit cycle and situation will be different to make the transaction more versatile and adaptable. The occurrence of special circumstances can also be more consistent with the actual situation, thus ultimately improving the degree of integration of theoretical teaching and actual conditions. Initially set implementation rules (see Table 3):

Table 3 Product unit price under different billing periods

\begin{tabular}{|l|l|l|l|}
\hline & Original term & Current term & unit price(\%) \\
\hline T/T & 0 & Wire transfer & Up 0 \\
\hline O/A & 1 & Bookkeeping trade & Up 5 \\
\hline D/A & 2 & Tax form & Up 5 \\
\hline D/P & 3 & Forward payment & Up 8 \\
\hline L/C & 4 & Letter of credit & Up 10 \\
\hline
\end{tabular}




\section{Case presentation}

Based on the establishment of the Shanghai Free Trade Zone, due to the increase in domestic labor costs, enterprises can only rediscover the new raw material procurement market. Optimize products through different trade methods and different accounting periods, so that the final benefits of the company increase.If you follow the "checklist" your paper will conform to the requirements of the publisher and facilitate a problem-free publication process.

\subsection{Raw material procurement.}

Team A expects to expand production in the next year, adding about 6 automatic lines. In order to reduce the cost of raw materials, after calculation, it decided to order an additional 6 R1, 6 R2 and 2 in the first quarter of the year. In the quarter, we also ordered an additional six R1 and six R2 in advance, and selected foreign markets to reduce costs. The team will need to pay an additional $\$ 720,000$ for raw materials in the third quarter and $\$ 720,000$ for the fourth quarter. In addition, under the conditions of raw material transportation that need to be considered in the original production, additional consideration will be given to the procurement of raw materials under new market conditions.

\subsection{Order delivery options.}

In the first quarter, Team A produced a total of six R1 products. The unit price of each product on the order was $50 \mathrm{w}$, and the quality reached 95 or more. The minimum required product quality of the order to be submitted was 80 or more. The delivery date is in the fourth quarter. In order to obtain higher profits, after considering their own funds, Team A chooses CPT delivery method, so as to reduce the quality of each product by $15 \%$, increase $20 \%$ of each product. The unit price, from 500,000 to $600,000 /$ piece, except for the cost of delivery costs, each product can still earn $10 * 6-5=550,000$ yuan more profit than the original.

\subsection{Account selection.}

The A team has sufficient funds this year, and will not consider the need to expand production capacity for the next year. Therefore, in the last choice of the six R1 orders, the time period is longer than the fourth quarter, but the unit price increase is larger. The $\mathrm{L} / \mathrm{C} \mathrm{L} / \mathrm{C}$ can eventually increase by $10 \%$, or 50,000 , on the basis of each unit price of 500,000 , which can increase the profit by $5 * 6=300,000$. In the end, the company maximizes its profits while ensuring operations.

\section{Conclusion}

The sand table simulation teaching system has been proved an excellent teaching mode and means for the experimental teaching of economics and management, and widely used in the experimental courses of major universities across the country. The application of international trade awareness in the sand table simulation teaching platform improves the sand table teaching system. By introducing international trade related simulation, the novel system enhances its operation authenticity and renders students to aware of the international trade factors whiling practicing the business management to consolidate their knowledge system of economics and management, which has great practical significance and promotion value for the development of sand table teaching.

\section{References}

[1] ZHANG Jing-yuan, ZHAO Yue, WANG Dong-di. Research of “Four-Stage” Teaching Method for "Enterprise Sand-Table Simulative Operation and Competition" Course. Research and Exploration in Laboratory, 2011(3):365-368.In Chinese.

[2] YIN Lei. Exploration on Sand Table Simulation Experimental Teaching of Enterprise Strategic 
Management. Research and Exploration in Laboratory, 2010,11:312-315.In Chinese.

[3] YU Yi-qiao. Introducing ERP Sand Table Simulation into Economy and Administration Teaching Reform [J]. Experiment Science \& Technology, 2006(6):93-95.

[4] Ding Min.Discussion on the Bilingual Teaching Model of International Commercial Law Course [J].Journal of Weifang University, 2010(2).In Chinese.

[5] ZHAO Bing-mei,ZHAO Li-qiang.Study on the Curriculum Practice Teaching System for the Management of Applied Talents in Economics and Management[J].Experimental Technology and Management,2009,26(5).

[6] YU Ming-liang, TAO Tian. Development and Application of Sand Table Experimental Platform with the Integration of Touch and Control [J]. Research and Exploration in Laboratory, 2015(1): 262-265.In Chinese. 